\title{
Assessment of cytotoxicity and genotoxicity of stem bark extracts from Canarium odontophyllum Miq. (dabai) against HCT 116 human colorectal cancer cell line
}

\author{
Dayang Fredalina Basri ${ }^{{ }^{*}}$ D , Zafira Ayushah Zainul Alamin ${ }^{1}$ and Kok Meng Chan²
}

\begin{abstract}
Background: Canarium odontophyllum Miq. is a plant species widely known as 'dabai' and can be vastly found in Sarawak. The aim of this study was to assess the cytotoxic and genotoxic effect of extracts from stem bark of C. odontophyllum against HCT 116 human colorectal cancer cell line.

Method: The $\mathrm{I}_{50}$ values of the aqueous, methanol, and acetone extracts against $\mathrm{HCT} 116$ cells as well as the acetone extract against human colon fibroblast cell line CCD-18co were determined using the MTT assay. The concentration of the extracts ranged from 12.5 to $200 \mu \mathrm{g} / \mathrm{ml}$ at treatment time of 24, 48 and $72 \mathrm{~h}$. Annexin V-FITC/PI labelling assay was employed to determine mode of HCT 116 cell death induced by acetone extract at $48 \mathrm{~h}$. The DNA damage induced by the extract in HCT 116 cells was detected using alkaline comet assay at 30 min of $I C_{10}$ and $I C_{25}$ treatment.

Results: Acetone extract exhibited the highest cytotoxic effect against HCT 116 cells compared to methanol and aqueous extract at 24, 48 and 72 h. Despite no cytotoxic effect by acetone extract against CCD-18co cells at 24 and $48 \mathrm{~h}$, however at $72 \mathrm{~h}, \mathrm{CCD}-18 \mathrm{co}$ cells proliferated. Apoptosis assessment using Annexin V-FITC/PI labelling assay revealed that the primary cell death was via apoptosis after $48 \mathrm{~h}$ treatment. Low doses of acetone extract from stem bark of C. odontophyllum showed significant DNA damage in HCT 116 cells with tail moment of $6.187 \pm 0.718$ A.U and $7.877 \pm 0.142$ A.U, respectively.
\end{abstract}

Conclusions: Acetone extract from stem bark of $C$. odontophyllum has high potential in the development of anticancer agent against HCT 116 cells with no cytotoxic effect against human colon fibroblast cells.

Keywords: Canarium odontophyllum, Dabai, Colorectal cancer, HCT 116, CCD-18co, Cytotoxicity, Apoptosis, DNA damage

\section{Background}

Colorectal cancer or colon cancer is defined as an uncontrollable cell growth at the lower part of the digestive system that is the large intestine [1]. Colorectal cancer is one of the main causes to high mortality and morbidity rate of cancer. Moreover, colorectal cancer is more frequent in the industrialized world than in developing countries [2]. Colorectal cancer falls in second highest mortality and morbidity rate followed by lung cancer,

\footnotetext{
* Correspondence: dayang@ukm.edu.my

${ }^{1}$ School of Diagnostic and Applied Health Sciences, Faculty of Health Sciences, Universiti Kebangsaan Malaysia, Jalan Raja Muda Abdul Aziz, Kuala Lumpur 50300, Malaysia
}

Full list of author information is available at the end of the article gastric cancer and breast cancer. In Malaysia, colorectal cancer mostly occurs in male and third in frequency among females. Colorectal cancer is common among the age group of 50 years old and above [3].

Plant derived anti-cancer agents play an important role in cancer chemotherapy [4]. Additionally, plant derived anti-cancer agents are known to be safer and give less side effects when in comparison with those synthetic anti-cancer agents available [5]. Canarium odontophyllum Miq. is a type of plant that is known as 'dabai' or 'Borneo olive'. It can be found in Sarawak, Malaysia especially in Sibu, Sarikei and Kapit [6]. It belongs in the Burseraceae family and Canarium L. genus [7]. The fruit of $C$. odontophyllum is oval with a purplish skin and has 
a single seed along with a hard and thick endocarp [8]. Almost all parts of the plant were tested for medical researches including the fruit, peel, shell of the seed, pulp, leaf and stem bark. The pulp extract from C. odontophyllum fruit was found to inhibit the growth of Candida glabrata [9]. The leaf and shell extracts from C. odontophyllum were shown to have antimicrobial activity against a wide range of pathogenic bacteria [10] whereas both the leaf and stem bark of C. odontophyllum demonstrated promising anticancer property [11]. However, previous study merely reported preliminary screening of cytotoxic activity against human colorectal carcinoma HCT 116 cell line attributed to the presence of flavonoid, tannin, saponin, terpenoid and phenolic compound [12]. Damage to DNA always occurs from endogenous and exogenous agents such as reactive oxygen species (ROS) from cellular metabolism and ultraviolet light from the sun [13]. Chemical carcinogens, radiation and genotoxic anti-cancer agents can cause DNA damage [14]. When there is DNA damage, the damage itself will cause cell cycle arrest where it can lead to DNA repair or cell death via apoptosis [15]. Therefore the objective of the present study is to investigate the mechanism of cell death and to determine the genotoxic effect of extracts from the stem bark of $C$. odontophyllum against HCT 116 human colorectal cancer cell line.

\section{Methods}

\section{Plant material}

Stem bark of Canarium odontophyllum Miq. was obtained from Sarawak, Malaysia. All plant parts were identified and authenticated by Mr. Sani Miran and deposited in the Herbarium of the Universiti Kebangsaan Malaysia (UKM), Bangi, Selangor, Malaysia with a voucher specimen number of UKMB 40052.

\section{Preparation of plant extracts}

The stem bark of Canarium odontophyllum was extracted in three different solvents with different degree of polarity namely acetone, methanol and aqueous. To prepare a stock extract solution of $100 \mathrm{mg} / \mathrm{ml}, 100 \mathrm{mg}$ of acetone and methanol extract were dissolved with $1 \mathrm{ml}$ of $100 \%$ dimethyl sulfoxide (DMSO) whereas for aqueous extract, $1 \mathrm{ml}$ of distilled water was used as the diluent. The solution was mixed well with an autovortex until the solution was completely dissolved. All extracts were sterilized by passing through a $0.22 \mu \mathrm{M}$ membrane filter and were stored in airtight jars at $-20{ }^{\circ} \mathrm{C}$ refrigerator until further use.

\section{Preparation of cell culture}

HCT 116 and CCD-18co were obtained from American Type Culture Collection (ATCC) (Rockville, MD USA). HCT 116 cell line (ATCC Number: CCL-247 ${ }^{\mathrm{rm}}$ ) was cultured in McCoy 5A media (1x) (Sigma Aldrich, USA) whereas the normal human colon cell line, CCD-18co (ATCC Number: CRL-1790 ${ }^{\mathrm{rm}}$ ) was cultured in EMEM (Eagle's Minimum Essential Medium) (1x) (Sigma-Aldrich, USA). Culturing of HCT 116 and CCD-18co were carried out in a sterile laminar flow chamber to avoid any possible contamination. McCoy 5A and CCD-18co media were enriched with $10 \%$ fetal bovine serum. All incubations in this study were done at a high humidity environment of $5 \%$ carbon dioxide $\left(\mathrm{CO}_{2}\right)$ and at a temperature of $37{ }^{\circ} \mathrm{C}$. The cultured cells were observed and checked daily by using an inversion microscope to see the morphology and cell growth, cultured up to 70-90 \% confluence of cells. To subculture the cells, the old media was removed from the flask and phosphate buffer saline (PBS) was used to rinse the excess media. Solution of trypsin-EDTA $(0.25 \%$ trypsin/0.03 \% EDTA) was added to remove the cells from the surface of the tissue culture flask. Media was added to inactivate the trypsin solution and centrifuged at $1000 \mathrm{rpm}$ for $3 \mathrm{~min}$. The cells were collected and transferred to a new labelled flask with a fresh media. Subculture of cells was done every 2 to 3 days for HCT 116 cell line and 4 to 5 days for CCD-18co cells.

\section{Evaluation of cytotoxic activity}

MTT assay [16] was performed to evaluate cytotoxicity of aqueous, methanol, and acetone extracts at concentration ranging from $12.5 \mu \mathrm{g} / \mathrm{ml}-200 \mu \mathrm{g} / \mathrm{ml}$ at 24,48 and $72 \mathrm{~h}$ against HCT 116 cells as well as acetone extract at 24, 48 and $72 \mathrm{~h}$ against CCD-18co. The cells were counted to achieve a concentration of $5.0 \times 10^{4}$ cells $/ \mathrm{ml}$. A total volume of $200 \mu \mathrm{l}$ of cell suspension was seeded in each well of the 96-microtiter plate. The seeded cells were incubated for $24 \mathrm{~h}$ before they were treated with each of the extract. Menadione was used as a positive control whereas the untreated cells comprised the HCT 116 cells in the media was used as negative control. A total volume of $200 \mu \mathrm{l}$ of sample treatment was added in each well and incubated for 24,48 and $72 \mathrm{~h}$ prior to addition of $20 \mu \mathrm{l}$ of MTT (3-(4,5-dimethylthiazol-2-yl)-2,5-diphenyltetrazolium bromide) at $5 \mathrm{mg} / \mathrm{ml}$ to each of the well and left for $4 \mathrm{~h}$ incubation. About $200 \mu \mathrm{l}$ of DMSO solution was added to each well to dissolve the formazan crystals at room temperature and was then incubated for $15 \mathrm{~min}$. The plate was shaken on an automatic mixer for $5 \mathrm{~min}$ and the absorbance was read by using an ELISA plate reader at a wavelength of $570 \mathrm{~nm}$. The percentage of cell viability was calculated using the formula given below:

$$
\text { Cell viability (\%) }=\frac{\text { Mean of treated sample }}{\text { Mean of negative control }} \times 100 \%
$$

The percentage of cell viability against the concentration of test compounds was plotted. The half maximal 
inhibition concentration $\left(\mathrm{IC}_{50}\right)$ which is the concentration of sample that inhibits cell growth was obtained from the plotted graph.

\section{Determination of mode of cell death}

Flow cytometry Annexin V-FITC/PI assay [17] was used to determine the mode of cell death induced by the tested compound. A total volume of $3 \mathrm{ml}$ of HCT 116 suspension cells at $5 \times 10^{4}$ cells $/ \mathrm{ml}$ were seeded in each well of the 6-well microtitre plate and incubated for $24 \mathrm{~h}$. The cells were treated with acetone extract at $25 \mu \mathrm{g} / \mathrm{ml}, 50 \mu \mathrm{g} / \mathrm{ml}, 100 \mu \mathrm{g} / \mathrm{ml}$ and $200 \mu \mathrm{g} / \mathrm{ml}$, then the $3 \mathrm{ml}$ of the treated sample was added into the 6-well microtitre plate and incubated for $48 \mathrm{~h}$. Next, the cells were washed with $1 \mathrm{ml}$ of PBS solution and trypsinized with $500 \mu \mathrm{l}$ of trypsin-EDTA to be collected into the same centrifuge tube for each well and was then centrifuged at $2500 \mathrm{rpm}$ for $5 \mathrm{~min}$. The supernatant was discarded and the process was repeated 3 times. A total of $200 \mu \mathrm{l}$ of annexin binding buffer $(1 \mathrm{x})$ followed by $5 \mu \mathrm{l}$ of Annexin V-FITC (eBioscience, Austria) was added into the tube and left for $15 \mathrm{~min}$ in ice. Next, $10 \mathrm{ul}$ of propidium iodide (eBioscience, Austria) at $20 \mu \mathrm{g} / \mathrm{ml}$ was added and incubated in ice condition for another two minutes and finally, $200 \mu \mathrm{l}$ of annexin binding buffer (1x) (eBioscience, Austria) was added into each tube. Lastly, the solution in the centrifuge tube was transferred into a Falcon tube to be analysed by flow cytometry (BD FASCCanto II) with Cell Quest software (BD Sciences, America).

\section{Alkaline comet assay}

Alkaline comet assay [18] was used to assess gentotoxic damage of HCT 116 by acetone extract from C. odontophyllum stem bark at $\mathrm{IC}_{10}$ and $\mathrm{IC}_{25}$ values whereas menadione was used as the positive control at $\mathrm{IC}_{25}$ value. A total of $3 \mathrm{ml}$ of HCT 116 suspension cell with concentration at $5 \times 10^{4}$ cells $/ \mathrm{ml}$ was seeded in each well of 6-well microtitre plate and incubated for $24 \mathrm{~h}$. The cells were then treated with acetone extract and left to incubate for $30 \mathrm{~min}$ before all the media in the well was collected into a centrifuge tube. The wells were washed twice with PBS solution and the cells were trypsinized with trypsin-EDTA solution. The solutions were all combined and were centrifuged at $2500 \mathrm{rpm}$ for $5 \mathrm{~min}$. The supernatant in each centrifuge tubes were discarded and this process was repeated. The low melting point agar (LMPA) and normal melting point agar (NMPA) (Sigma Aldrich, USA) were preheated until the agar melted. When the NMPA reached a temperature of $37^{\circ} \mathrm{C}$, a total of $100 \mu \mathrm{L}$ of NMPA was pipetted onto a frosted slide and a coverslip (50 mm X $22 \mathrm{~mm}$ ) was placed on top of the slide and was then taken out slowly after the agar hardened. Next, about $80 \mu \mathrm{L}$ of LMPA was added into each sample tube on top of the prepared NMPA slide and a coverslip was placed slowly onto the two layers of gel. The coverslip was again taken out slowly and was placed in a coplin jar filled with the lysing solution and cooled at $4{ }^{\circ} \mathrm{C}$ for $24 \mathrm{~h}$ before the slides were taken out and placed on the electrophoresis tank. Electrophoresis buffer was added into the tank to immerse the slide for 20 min to allow the DNA strands to unwind. The electrophoresis process was carried out for $20 \mathrm{~min}$ at $25 \mathrm{~V}$ and $300 \mathrm{~mA}$ after which the slides were rinsed with neutralizing buffer three times for every $5 \mathrm{~min}$. The slides were then stained with $50 \mu \mathrm{l}$ of ethidium bromide (Sigma Aldrich, USA) at $20 \mu \mathrm{g} / \mathrm{ml}$. For each slide, 50 single and isolated cells were analysed for any DNA damage under a fluorescent microscope (Biochrom ASYS, UK).

\section{Statistical analysis}

All data were analysed by using SPSS Software Version 22. All data were done in triplicate and were expressed as the mean \pm S.E.M. from three different experiments. One way ANOVA was used to measure statistical differences between the mean in all experiments. The statistical difference was indicated with value $p<0.05$.

\section{Results}

\section{Assessment of cytotoxic activity}

The result for cytotoxic activity of acetone, methanol and aqueous extract from stem bark of C. odontophyllum against HCT 116 cells were displayed respectively, in Figs. 1, 2 and 3 and compiled in Table 1. Acetone extract showed a higher cytotoxic effect at $\mathrm{IC}_{50}$ value of $50 \pm 10.69 \mu \mathrm{g} / \mathrm{ml}$ (Fig. 1) compared with methanol extract at $\mathrm{IC}_{50}$ value of $65 \pm 2.89 \mu \mathrm{g} / \mathrm{ml}$ (Fig. 2) at $24 \mathrm{~h}$ of treatment. However, no cytotoxic effect was observed by the aqueous extract (Fig. 3) at the same treatment duration. At $48 \mathrm{~h}$, the acetone extract displayed the lowest $\mathrm{IC}_{50}$ of $25 \pm 5.20 \mu \mathrm{g} / \mathrm{ml}$ (Fig. 1) in contrast with methanol extract $\left(\mathrm{IC}_{50} 30 \pm 4.73 \mu \mathrm{g} / \mathrm{ml}\right)$ and aqueous extract $\left(\mathrm{IC}_{50} 112 \pm 6.11 \mu \mathrm{g} / \mathrm{ml}\right)$ as shown in Figs. 2 and 3, respectively. Table 1 summarised that the $\mathrm{IC}_{50}$ values of all three extracts obtained at $48 \mathrm{~h}$ were lower than the $\mathrm{IC}_{50}$ values at $24 \mathrm{~h}$. When the treatment was prolonged to $72 \mathrm{~h}$, the same profile was observed with acetone, methanol and aqueous extract with $\mathrm{IC}_{50}$ values of $40 \pm 2.89 \mu \mathrm{g} / \mathrm{ml}$ (Fig. 1), $45 \pm 7.64 \mu \mathrm{g} / \mathrm{ml}$ (Fig. 2) and $160 \pm 5.46 \mu \mathrm{g} / \mathrm{ml}$ (Fig. 3), respectively. The $\mathrm{IC}_{50}$ values obtained at $72 \mathrm{~h}$ were slightly higher than the $\mathrm{IC}_{50}$ values at $48 \mathrm{~h}$. However, there was no significant difference indicated between these values. Based on Fig. 4, menadione showed prominent cytotoxic activity against both HCT 116 and CCD-18co cells with $\mathrm{IC}_{50}$ of $8 \mu \mathrm{M}$ and $20 \mu \mathrm{M}$, respectively. In contrast with the normal colon cell line CCD-18co, Fig. 5 showed no cytotoxic effect by the acetone extract at 24 and $48 \mathrm{~h}$. However, when treatment was 


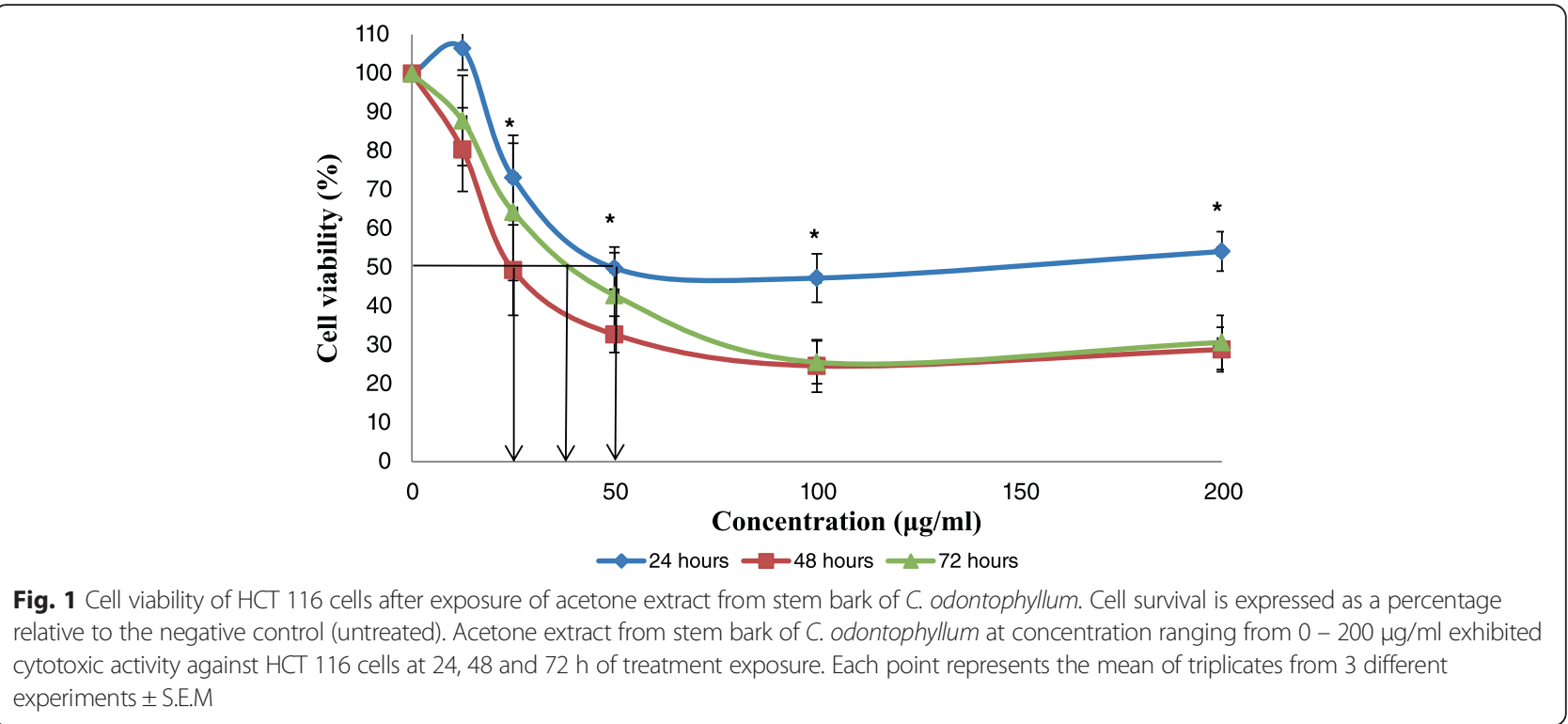

prolonged to $72 \mathrm{~h}$, CCD-18co cells proliferated significantly only at the lower doses.

\section{Assessment of mode of cell death}

Figure 6 showed the cytogram of HCT 116 induced with acetone extract at $25 \mu \mathrm{g} / \mathrm{ml}$ to $200 \mu \mathrm{g} / \mathrm{ml}$ after $48 \mathrm{~h}$ of treatment as determined by flow cytometry using Annexin V-FITC/PI assay. Based on Fig. 7, there is an apparent decrease in percentage of viable HCT 116 cells after $48 \mathrm{~h}$ treatment of acetone extract in a dosedependent manner. One-way ANOVA analysis revealed that there was a significant difference $(p<0.05)$ of percentage of viable cells when treated at high doses $(100 \mu \mathrm{g} / \mathrm{ml}$ and $200 \mu \mathrm{g} / \mathrm{ml})$ of acetone extract which were at $30.3 \pm 1.474 \%$ and $4.4 \pm 1.68 \%$, respectively when in comparison with the percentage of viable cells of the negative control $(89.367 \pm 3.531 \%)$. In accordance with the result, a significant $(p<0.05)$ increased of percentage of apoptotic cells after treatment with acetone extract can be observed at concentration $100 \mu \mathrm{g} / \mathrm{ml}$ $(58.9 \pm 1.158 \%)$ and $200 \mu \mathrm{g} / \mathrm{ml}(88.53 \pm 1.763 \%)$ when compared to the percentage of apoptotic cells in negative

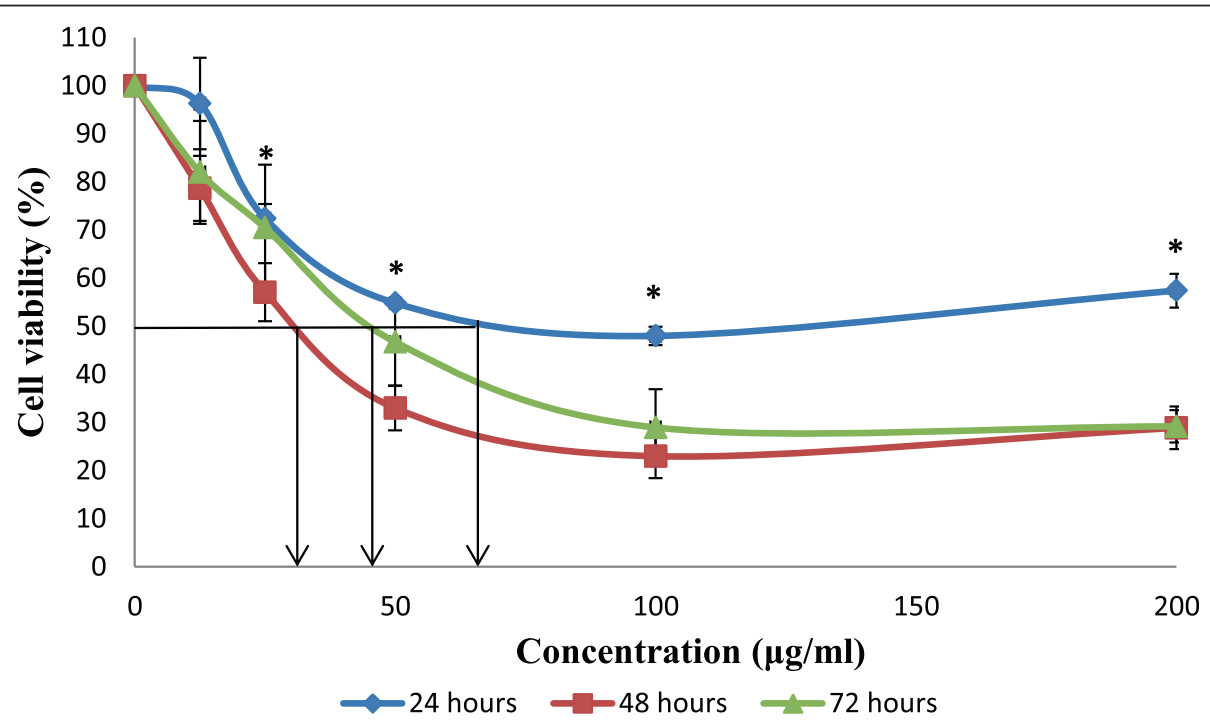

Fig. 2 Cell viability of HCT 116 cells after exposure of methanol extract from stem bark of C. odontophyllum. Cell survival is expressed as a percentage relative to the negative control (untreated). Methanol extract from stem bark of C. odontophyllum at concentration ranging from 0 - $200 \mu \mathrm{g} / \mathrm{ml}$ exhibited cytotoxic activity against HCT 116 cells at 24,48 and 72 h of treatment exposure. Each point represents the mean of triplicates from 3 different experiments \pm S.E.M 


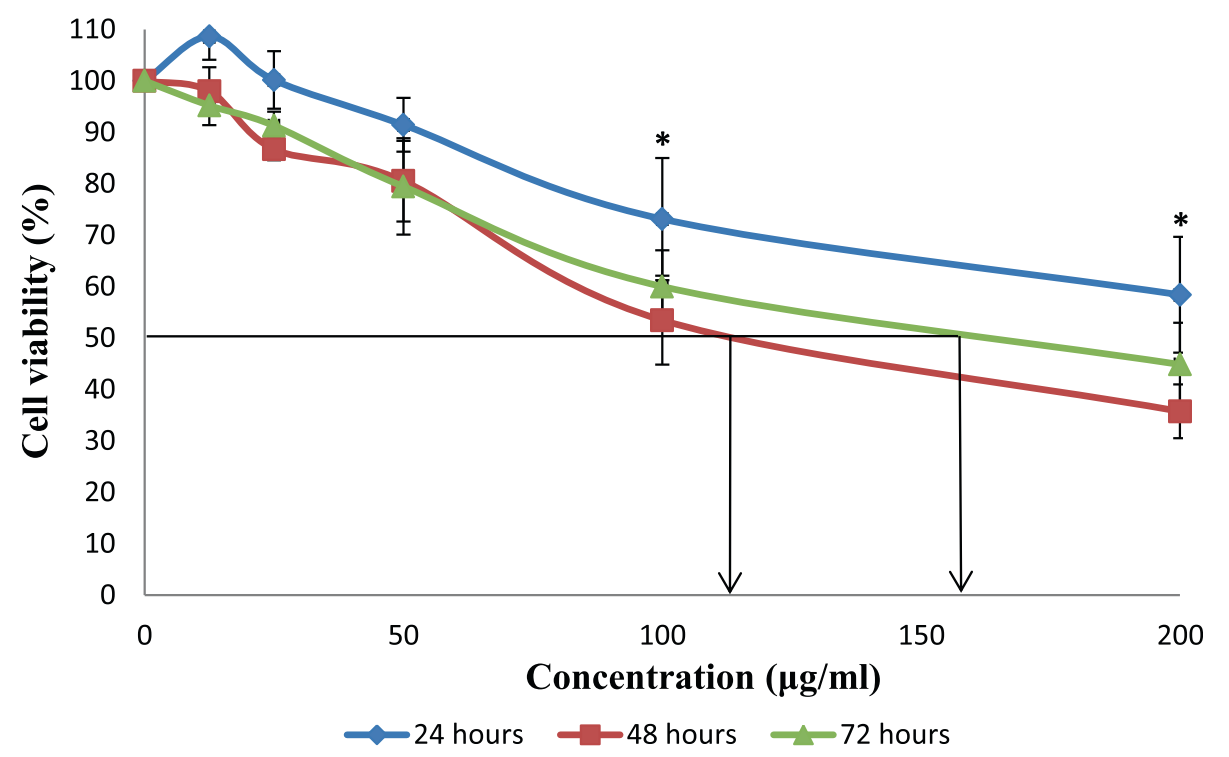

Fig. 3 Cell viability of HCT 116 cells after exposure of aqueous extract from stem bark of C. odontophyllum. Cell survival is expressed as a percentage relative to the negative control (untreated). Aqueous extract from stem bark of $C$. odontophyllum at concentration ranging from $0-200 \mu \mathrm{g} / \mathrm{ml}$ exhibited cytotoxic activity against HCT 116 cells at 24, 48 and $72 \mathrm{~h}$ of treatment exposure. Each point represents the mean of triplicates from 3 different experiments \pm S.E.M

control $(5.667 \pm 2.234 \%)$. A significant $(p<0.05)$ increased in necrotic cells can only be observed at concentration $100 \mu \mathrm{g} / \mathrm{ml}$ with a total of $10.8 \pm 2.451 \%$ compared to the negative control which wgs at $4.767 \pm 1.378 \%$. The positive control, goniothalamin, displayed significant percentage of viable, apoptotic and necrotic cell population at $25.767 \pm 3.733 \%, 58.333 \pm 4.694 \%$ and $15.9 \pm 1.00 \%$, respectively.

\section{Assessment of genotoxic activity}

Figure 8 presented tail moment of HCT 116 cells after treatment with acetone extract at $8 \mu \mathrm{g} / \mathrm{ml}\left(\mathrm{IC}_{10}\right.$ value) and $15 \mu \mathrm{g} / \mathrm{ml}\left(\mathrm{IC}_{25}\right.$ value) for $30 \mathrm{~min}$. One-way ANOVA analysis displayed a significant $(p<0.05)$ increased of HCT 116 cell tail moment at both concentration $8 \mu \mathrm{g} / \mathrm{ml}$ ( $\mathrm{IC}_{10}$ value) and $15 \mu \mathrm{g} / \mathrm{ml}\left(\mathrm{IC}_{25}\right.$ value) when compared to the negative control $(1.080 \pm 0.239$ A.U.) which were

Table 1 Comparison of $\mathrm{IC}_{50}$ values of extracts against $\mathrm{HCT} 116$

\begin{tabular}{|c|c|c|c|}
\hline \multirow{2}{*}{$\begin{array}{l}\text { Extract } \\
\text { Time of } \\
\text { treatment } \\
\text { exposure }\end{array}$} & \multicolumn{3}{|l|}{$\mathrm{IC}_{50}$ value } \\
\hline & Acetone extract & Methanol extract & Aqueous extract \\
\hline $24 \mathrm{~h}$ & $50 \pm 10.69 \mu \mathrm{g} / \mathrm{ml}$ & $65 \pm 2.89 \mu \mathrm{g} / \mathrm{ml}$ & $>200 \mu \mathrm{g} / \mathrm{ml}$ \\
\hline $48 \mathrm{~h}$ & $25 \pm 5.20 \mu \mathrm{g} / \mathrm{ml}$ & $30 \pm 4.73 \mu \mathrm{g} / \mathrm{ml}$ & $112 \pm 6.11 \mu \mathrm{g} / \mathrm{ml}$ \\
\hline $72 \mathrm{~h}$ & $40 \pm 2.89 \mu \mathrm{g} / \mathrm{ml}$ & $45 \pm 7.64 \mu \mathrm{g} / \mathrm{ml}$ & $160 \pm 5.46 \mu \mathrm{g} / \mathrm{ml}$ \\
\hline
\end{tabular}

The $\mathrm{IC}_{50}$ values of, acetone, methanol and aqueous extract from stem bark of C.odontophyllum against HCT 116 cell line at 24,48 and $72 \mathrm{~h}$ of treatment. Data represents the mean of triplicates from 3 different experiments \pm error in S.E.M
$6.187 \pm 0.718$ A.U and $7.877 \pm 0.142$ A.U, respectively. Based on the study, the value of tail moment increased as the concentration increased despite no significant difference $(p>0.05)$ between these values. The positive control, menadione, at $5 \mu \mathrm{M}\left(\mathrm{IC}_{25}\right)$ exhibited significant $(p<0.05)$ tail moment of HCT 116 cells which was at $12.863 \pm 0.441$ A.U. The percentage of DNA tail of HCT 116 cells after treatment with acetone extract at $8 \mu \mathrm{g} / \mathrm{ml}\left(\mathrm{IC}_{10}\right.$ value) and $15 \mu \mathrm{g} / \mathrm{ml}\left(\mathrm{IC}_{25}\right.$ value) for $30 \mathrm{~min}$ can be observed in Fig. 9 . According to one-way ANOVA analysis, there was a significant difference $(p<0.05)$ between percentage of DNA tail of treated HCT 116 cells and the negative control $(7.866 \pm 0.939 \%)$ with values of $15.799 \pm 0.673 \%$ and $18.432 \pm 0.751 \%$, respectively. Again, the percentage of tail intensity seemed to increase as the concentration increases, despite no significant difference $(p>0.05)$ between these values. The positive control, menadione, at $5 \mu \mathrm{M}\left(\mathrm{IC}_{25}\right)$ revealed significant higher $(p<0.05)$ percentage of tail intensity in HCT 116 cells which was at $47.422 \pm 2.02 \%$. In addition, Fig. 10 showed the DNA migration in treated HCT116 cells and no DNA migration was seen in untreated HCT 116 cell (negative control).

\section{Discussion}

The search for a potential anticancer agent has been a challenge for scientists with regards to existence of side effects and drug resistance. Plant-derived anticancer agents are likely to be more effective in the cancer treatment [19]. In this study, evaluation of cytotoxic and genotoxic effects of extracts from stem bark of $C$. odontophyllum 


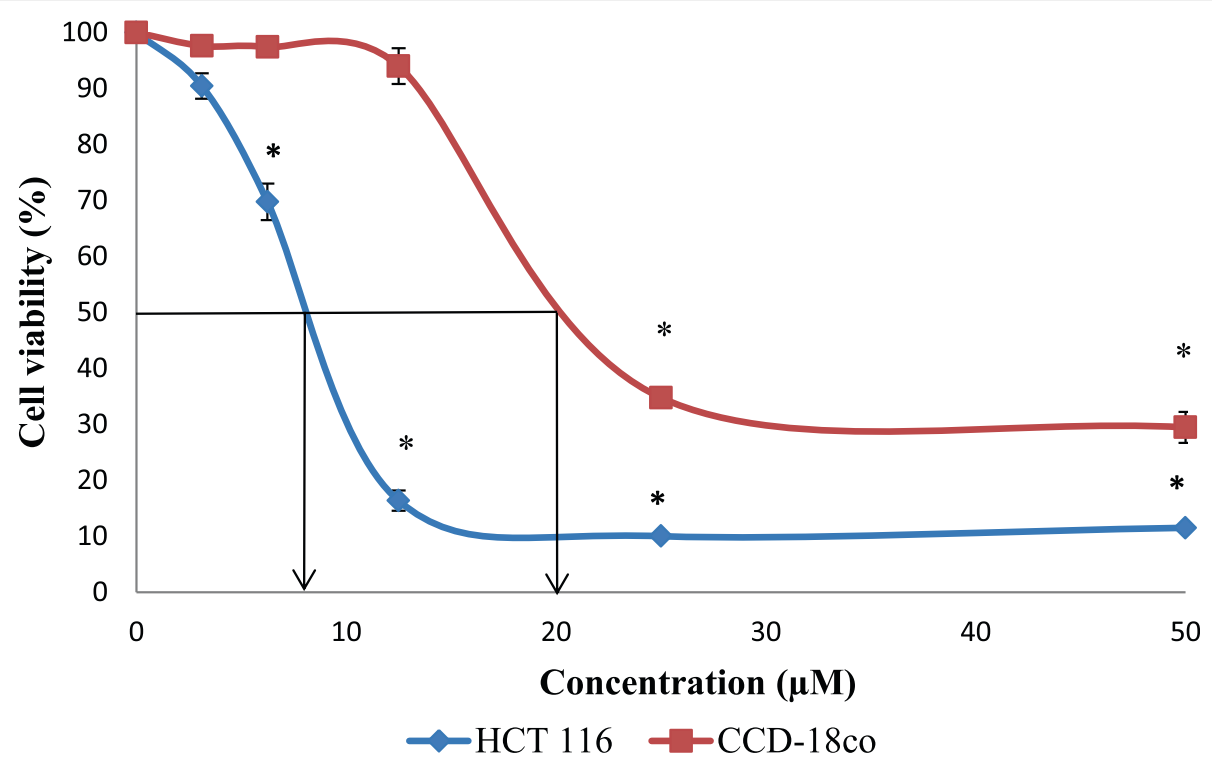

Fig. 4 Cell viability of HCT 116 and CCD-18co cells after exposure of Menadione. Cell survival is expressed as a percentage relative to the negative control (untreated). Menadione at concentration ranging from 0 - $50 \mathrm{Mm}$ exhibited cytotoxic activity against HCT 116 and CCD-18co cells at $24 \mathrm{~h}$ of treatment exposure. Each point represents the mean of triplicates from 3 different experiments \pm S.E.M

against human colorectal cancer cell HCT 116 was done and assessment of cytotoxic effect of acetone extract from stem bark of $C$. odontophyllum against normal colon cell CCD-18co was carried out.

From the MTT assay, acetone extract showed a higher cytotoxic effect compared with methanol extract whereas aqueous extract was not cytotoxic at $24 \mathrm{~h}$ of treatment. In the previous study, the same pattern of data was seen by all three extracts but at much higher $\mathrm{IC}_{50}$ values [10]. This may be because of the difference in the range of concentration used. The range of the concentration used in this study was smaller compared to the range of concentration used in the previous study. When HCT 116 cells were treated for $48 \mathrm{~h}$, the acetone extract again displayed the lowest $\mathrm{IC}_{50}$ value in contrast with methanol and aqueous extract. The $\mathrm{IC}_{50}$ values of all three extracts obtained in

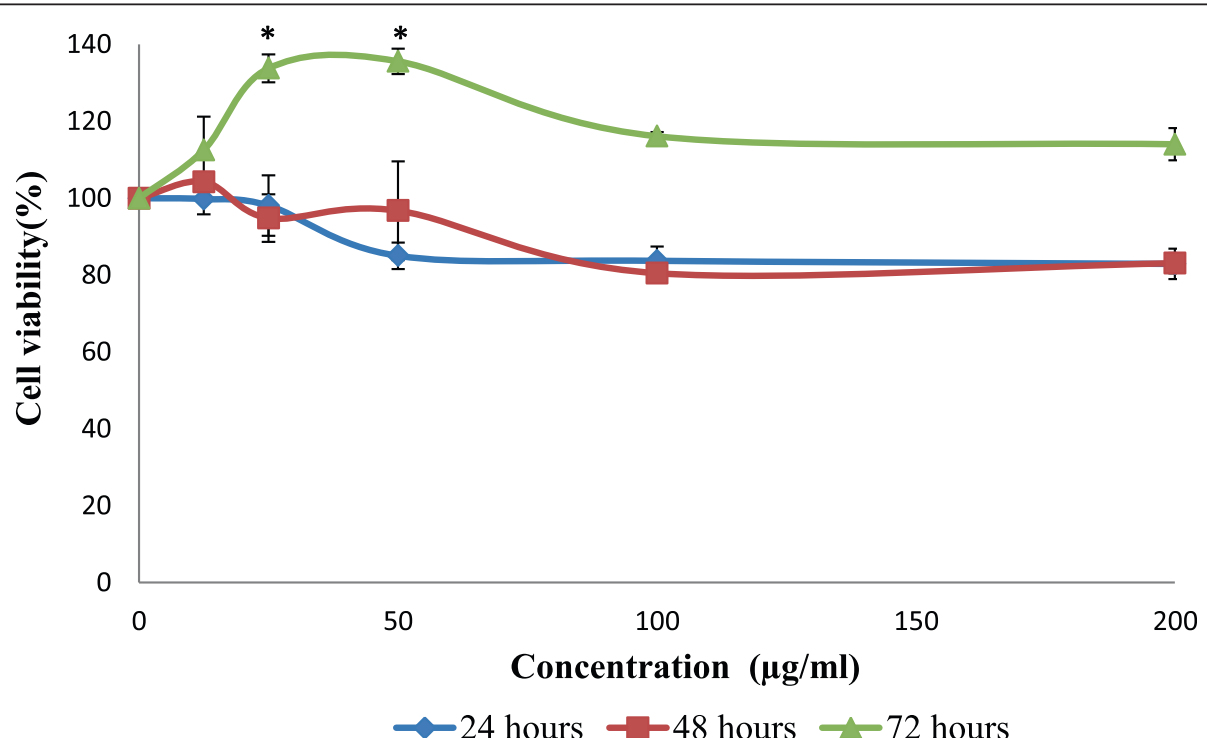

Fig. 5 Cell viability of CCD-18co cells after exposure of acetone extract from stem bark of C. odontophyllum. Cell survival is expressed as a percentage relative to the negative control (untreated). Acetone extract from stem bark of $C$. odontophyllum at concentration ranging from $0-200 \mu \mathrm{m} / \mathrm{ml}$ exhibited no cytotoxic activity against CCD-18co cells at 24, 48 and $72 \mathrm{~h}$ of treatment exposure. Each point represents the mean of triplicates from 3 different experiments \pm S.E.M 

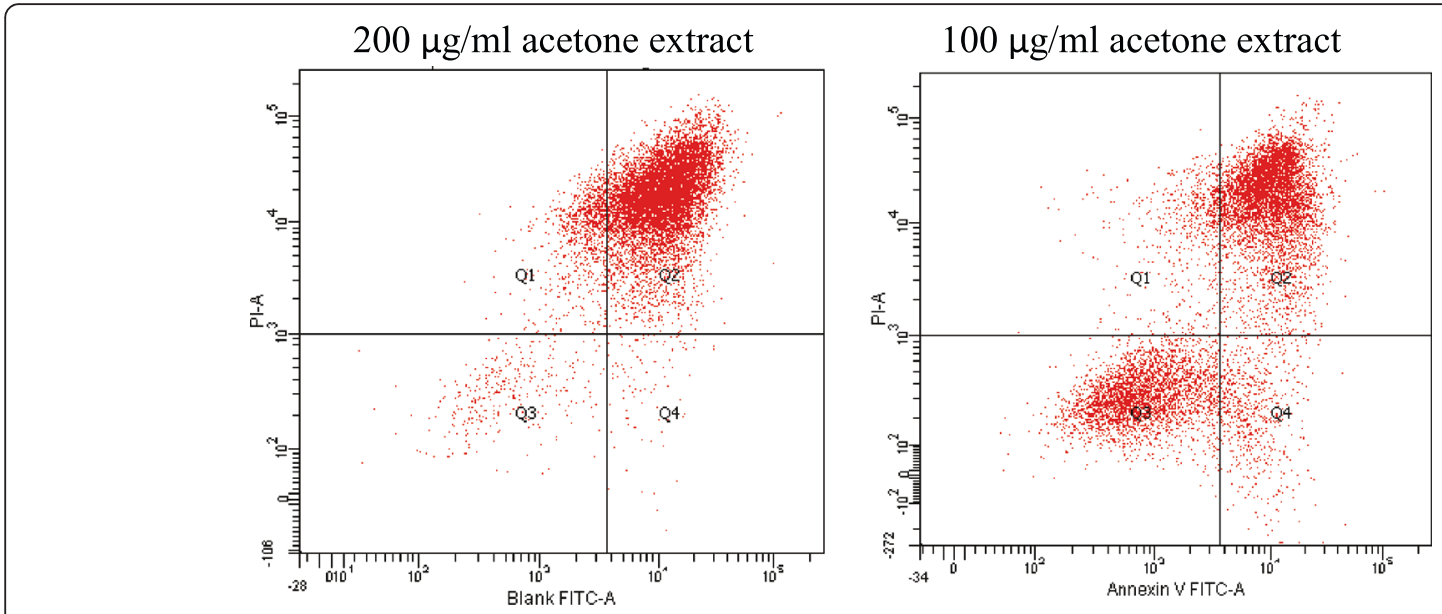

$50 \mu \mathrm{g} / \mathrm{ml}$ acetone extract

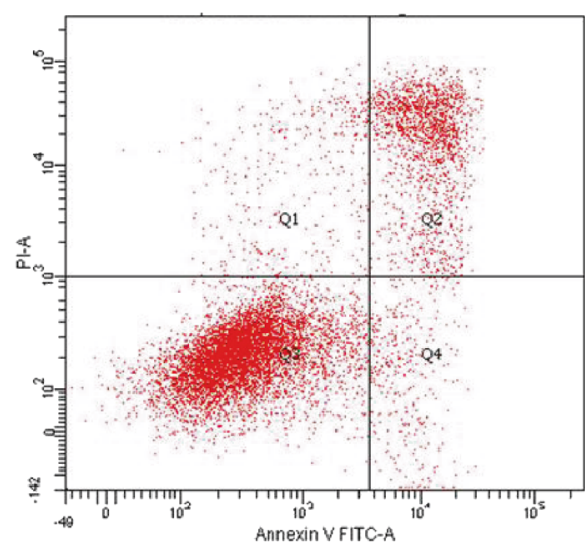

Negative control

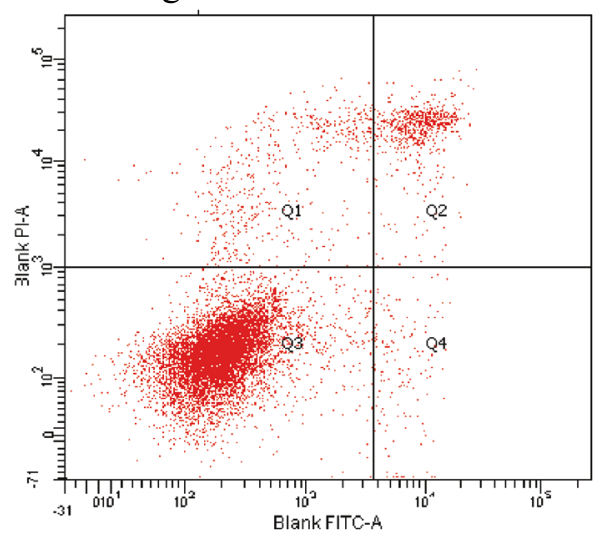

$25 \mu \mathrm{g} / \mathrm{ml}$ acetone extract

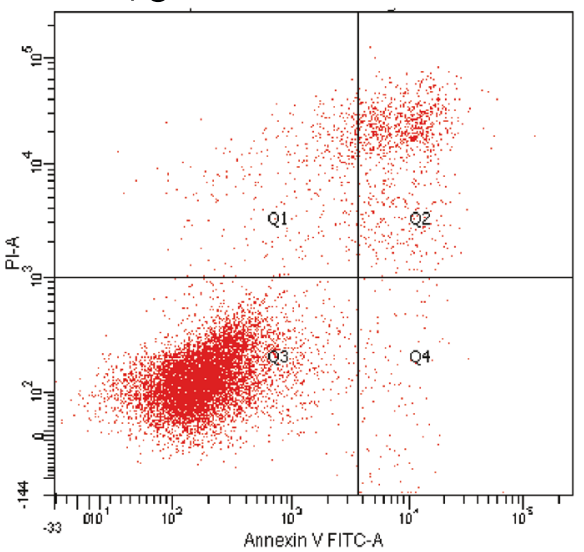

Goniothalamin $(50 \mu \mathrm{M})$

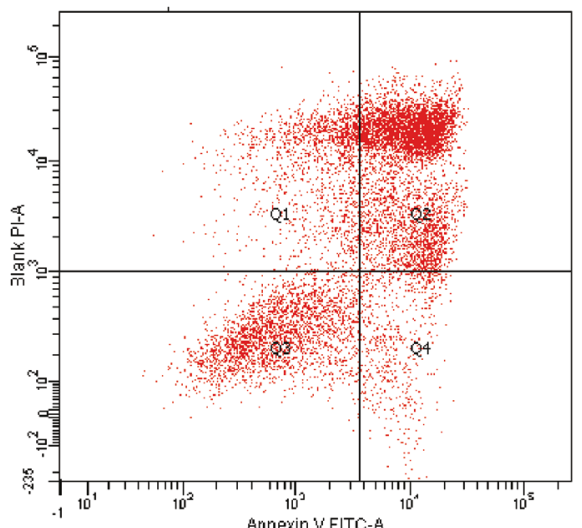

Fig. 6 Cytogram of HCT 116 cells induced with acetone extract. Cells were treated with acetone extract from stem bark of C. odontophyllum at concentration ranging from $25-200 \mu \mathrm{g} / \mathrm{ml}$ after $48 \mathrm{~h}$ of treatment

$48 \mathrm{~h}$ were lower than the $\mathrm{IC}_{50}$ values in $24 \mathrm{~h}$ and this indicated that the extracts gave a time-dependent cytotoxic activity. The longer the exposure of treatment, the lower the $\mathrm{IC}_{50}$ value and the higher is their toxic effect [20]. However, when the treatment was prolonged to $72 \mathrm{~h}$, the same profile was observed whereby acetone exerted the lowest $\mathrm{IC}_{50}$ value. Although the $\mathrm{IC}_{50}$ values obtained in $72 \mathrm{~h}$ were slightly higher than the $\mathrm{IC}_{50}$ values in $48 \mathrm{~h}$, there was no significant difference $(p>0.05)$ indicated between these values. 


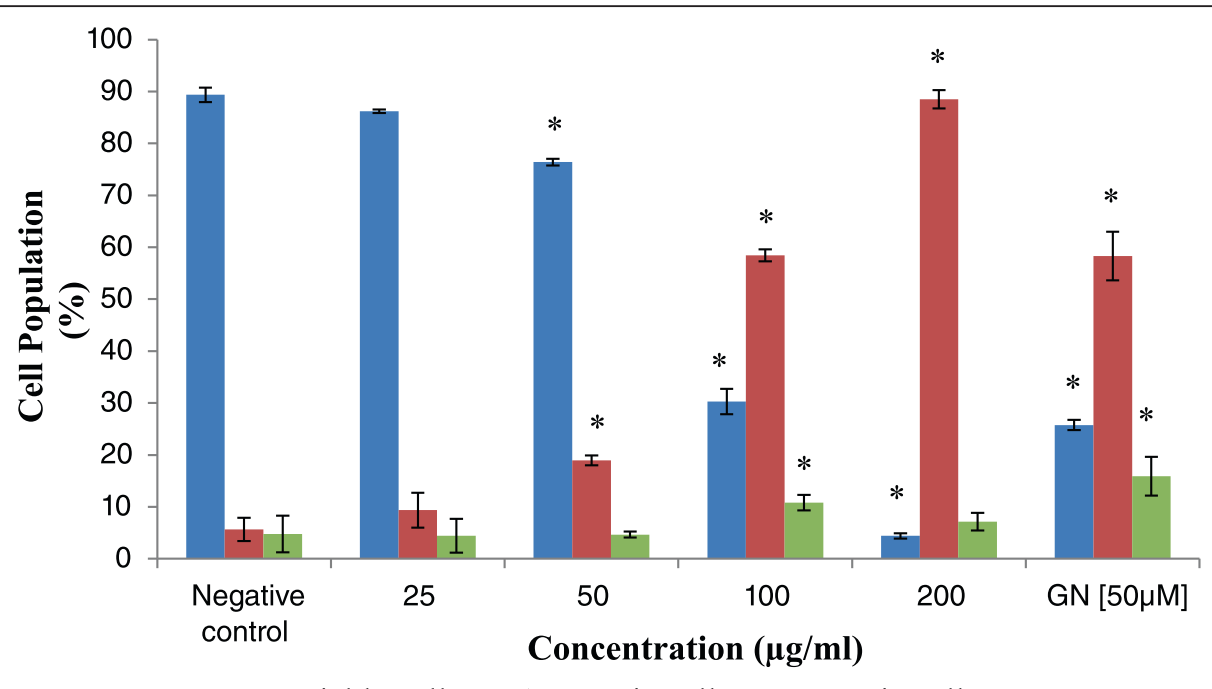

$\square$ Viable cell $\square$ Apoptotic cell $\square$ Necrotic cell

Fig. 7 Percentage of cell population of HCT 116 after 48 h treatment. Cells were treated with of acetone extract from stem bark of $C$. odontophyllum at concentration ranging from $25-200 \mu \mathrm{g} / \mathrm{ml}$ for $48 \mathrm{~h}$. Each data represents the mean of triplicates from 3 different experiments \pm S.E.M

From the present study, the methanol and acetone extract at $200 \mu \mathrm{g} / \mathrm{ml}$ produced higher percentage of cell viability than at $100 \mu \mathrm{g} / \mathrm{ml}$. Exogenous antioxidants that contain in the extract may give both good and bad outcome in redox condition. In addition, a few studies showed that exogenous antioxidants gave debatable results especially at high doses. The type, concentration and matrix of exogenous antioxidant from a natural compound are the features that affect the balance of the benefits [21].

Out of all three extracts, acetone extract exhibited the most potent cytotoxic activity with a significantly higher cytotoxic effect than aqueous extract but the cytotoxicity between acetone and methanol extract showed no significant difference. This finding correlates with the previous study which reported that acetone extract from the stem bark of C. odontophyllum [12] displayed the highest cytotoxic effect against HCT 116 cells and was also in agreement with acetone extract from the leaves of C. odontophyllum [11]. The cytotoxic activity of a plant against cancer cells is based on their phytochemical properties [22]. The phytochemical screening of aqueous, methanol and acetone extracts from stem bark of $C$. odontophyllum showed that all three extracts contain flavonoid, saponin, tannin, terpenoid and phenolic compounds [12]. The potent cytotoxic effect exerted by acetone extract may be caused by non-polar terpenoid compound. For example, a few terpenoid derivatives from Rhizoma curcumae were found to have antiproliferative properties against cancer cell lines [23]. Polyphenolic compounds such as flavonoid may also contribute to the antitumor activity. Flavonoids are

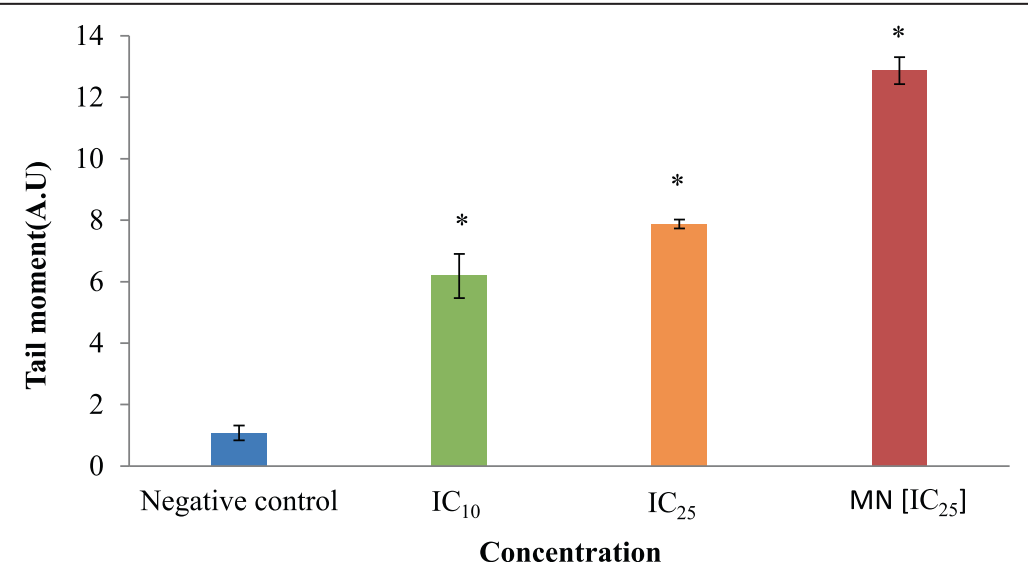

Fig. 8 Tail moment of HCT 116 cells after 30 min of treatment. Cells were treated with acetone extract from stem bark of C. odontophyllum for $30 \mathrm{~min}$. Each data represents the mean of triplicates from 3 different experiments \pm S.E.M 


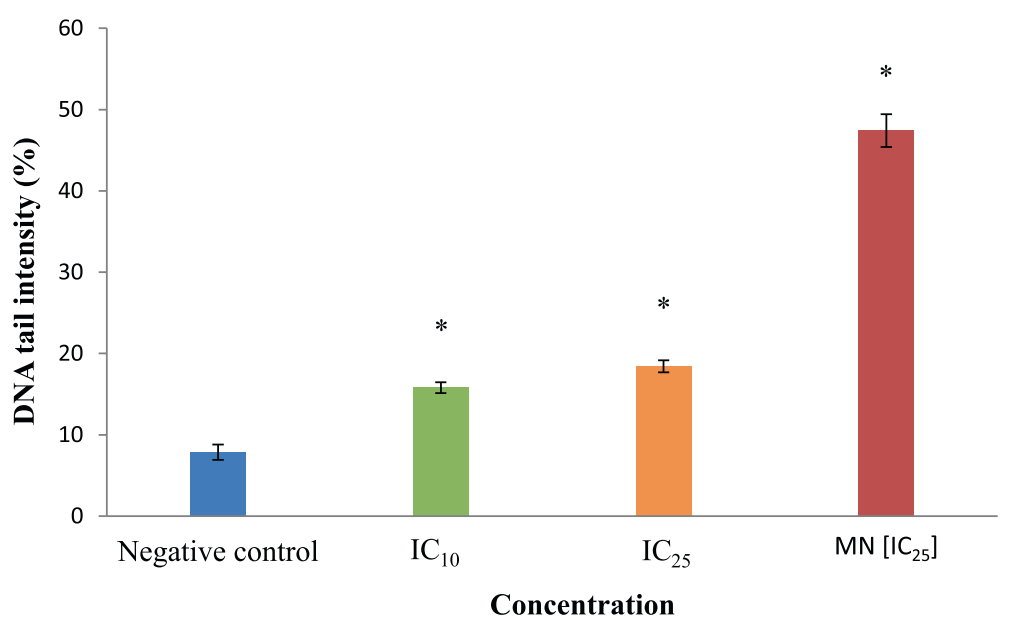

Fig. 9 DNA tail intensity of HCT 116 cells after 30 min of treatment. Cells were treated with acetone extract from stem bark of C. odontophyllum for $30 \mathrm{~min}$. Each data represents the mean of triplicates from 3 different experiments \pm S.E.M

known to have beneficial biological effects that include anti-inflammatory, anti-allergic, antimicrobial, anticarcinogenic and antitumor effects [24]. Based from the results obtained, acetone extract was chosen to proceed with the rest of the experiments as it is considered to be the most potent out of all extracts tested.

In general, effective anticancer agents have to execute or halt the cancer cells to live and at the same time will not exert any toxic effect towards the normal cells [25]. As example, extract from Eugenia jambolana Lam. are able to inhibit the growth of breast cancer cell line MCF-7aro and MDA-MB-231 but did not inhibit the growth of normal breast cells MCF10A [26]. Generally, antitumor agents show cytotoxicity against cells with higher growth activity by mechanisms such as the inhibition or suppression of increasing nucleic acid synthesis and metabolic pathways than in normal cells [27]. Selective killing towards cancer cells can be achieved by anticancer agents because the characteristics of cancer cells are not the same as the normal cells. Cancer cells are said to be under pressure and are destined to die. They depend highly on abnormalities of apoptosis signalling pathways to stay viable [28]. However, when treatment of acetone extract from stem bark of $C$.
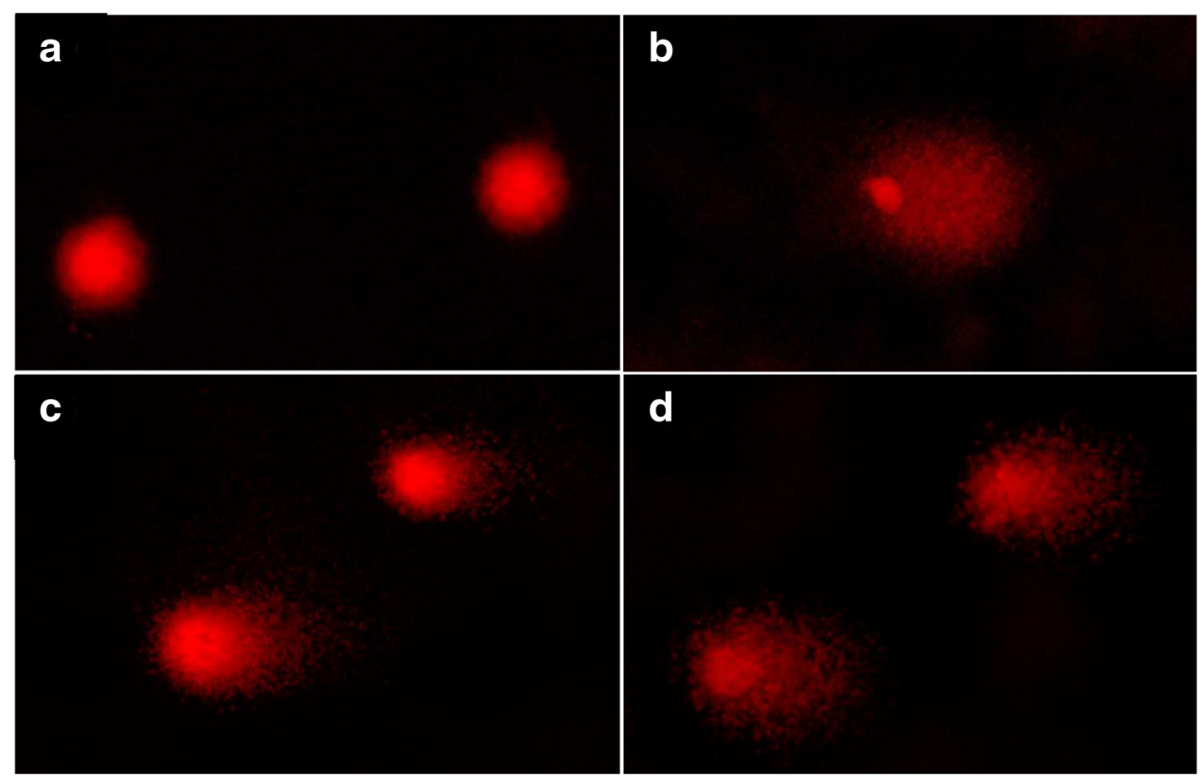

Fig. 10 Photo of a single HCT 116 cell stained with ethidium bromide under fluorescent microscope at 30 min. a Negative control: untreated cell (b) Menadione at IC25 (c) DNA migration of HCT 116 cell induced by acetone extract at IC10 (d) DNA migration of HCT 116 cell induced by acetone extract at $I \mathrm{C}_{25}$ 
odontophyllum was prolonged to $72 \mathrm{~h}, \mathrm{CCD}-18 \mathrm{co}$ cells proliferated at the lower doses. This may be due to the presence of compounds that contribute to the mitogenic activity of the cells [29].

Although the $\mathrm{IC}_{50}$ value obtained for CCD-18co cells was higher than the $\mathrm{IC}_{50}$ obtained for HCT 116 cells, the toxicity of menadione are general to both cells with its Selective Index (SI) value of 2.5. The SI can be achieved by calculating the ratio of $\mathrm{IC}_{50}$ value of normal cell and $\mathrm{IC}_{50}$ value of cancer cell. SI values that are higher than three are considered as selective toxicity which means that the compound gives selective toxicity to cancer cells but gives no harm or minimal toxicity to normal cells [30]. Hence, we can say that acetone extract from stem bark of $C$. odontophyllum exhibited selective toxicity towards colorectal cancer cell line HCT 116.

Mode of cell death assessment of acetone extract from stem bark of $C$. odontophyllum using flow cytometry Annexin V-FITC/PI labelling assay revealed that the primary cell death of HCT 116 cells was via apoptosis after $48 \mathrm{~h}$ treatment. Our findings demonstrated an increase of apoptotic cells and a decrease of viable cells with increasing concentration of acetone extract from stem bark of C. odontophyllum. It is said that plant-derived polyphenolic compounds act as antitumor compounds and have apoptosis-inducing properties in cancer cells [31]. Based on the previous study [10], acetone extract from stem bark of $C$. odontophyllum was found to have phenolic compounds and other phytochemicals such as saponin, terpenoid and tannin. A study found that acetone extract from stem bark of Cephaltaxus griffithii Hook f. induced apoptosis towards HeLa cells [32]. In addition, the mode of cell death of HL-60 cells after treatment with ethyl acetate extract from stem bark of Cudrania tricuspidata was via apoptosis [33]. Apoptosis was also the primary cell death of HCT 116 cells after treatment with ethanol extract from sporophyll of Undaria pinnatifilda [34].

The development of plant derived anticancer drug plays a vital role in the treatment of cancer [35]. Many synthetic drugs such as alkylating and antimetabolite agent can affect normal cell and produce side effects to cancer patient [36]. Apoptosis or programmed cell death has been the aim for treatment of cancer at many level of tumour development [37]. During apoptosis, apoptotic bodies undergo phagocytosis and will not submit itself to the inflammation process and may not cause disturbance towards nearby cell [38]. Apoptosis signalling pathways are divided into two mechanisms which are those that involved the mitochondria known as the intrinsic pathway or those that signals through death receptors namely the extrinsic pathway [29]. The specific pathway of apoptosis induced by acetone extract from stem bark C. odontophyllum is not fully investigated and understood yet.
Based from the outcomes of MTT assay and flow cytometry Annexin V-FITC/PI assay, the percentage of viable cells obtained were different in these two approaches. This may be due to the difference in the endpoint measurement of these assays [39]. MTT assay is based on the involvement of active mitochondria in living cell to produce succinate dehydrogenase enzyme in order to reduce MTT salt to formazan whereas flow cytometry Annexin V-FITC/PI assay is based on the detection of exposed phosphatidylserine on the outer part of the membrane in dead cells [16, 17]. Besides that, MTT assay can only measure living cell but not dead cell. Flow cytometry Annexin V-FITC/PI assay is able to measure percentage of both living and dead cell in a known amount of cell. The differences between these two assays may be contributing to the deviation of result obtained.

Cytotoxic effect induced by acetone extract from stem bark of C. odontophyllum towards HCT 116 cells may be caused by DNA damage and the detected genotoxicity might be the early mechanism of cell death via apoptosis. Alkaline comet assay was used to detect genotoxic effect of tested compound by measuring its DNA damage at single cell that can be observed under a fluorescent microscope whereas a comet head (nucleus) and its tail (DNA fragments) can be seen [40]. The concentrations used in this study were at $\mathrm{IC}_{10}$ and $\mathrm{IC}_{25}$ values that were obtained from the graph of cell viability versus concentration for acetone extract. A lower and noncytotoxic concentration was used to dodge any false positive result of dying or dead cells [41]. Among the frequently used comet parameters, percentage of DNA in tail and tail moment could offer the most precise result for the degree of damage [42].

In this study, $\mathrm{IC}_{10}$ and $\mathrm{IC}_{25}$ of acetone extract from stem bark of $C$. odontophyllum showed significant $(p<0.05)$ DNA damage in HCT 116 cells after 30 min of treatment. DNA is the key target by most cytotoxic anticancer drugs whether it acts directly through reactive metabolites or indirectly through the incorporation into DNA nucleotide analogues or by blockade of DNA-metabolizing functions such as DNA polymerase or topoisomerase. Cancer cells divide more repeatedly than normal cells and this cell division becomes the aim for anticancer agents where the most vital cell cycle phase is DNA replication. Most anticancer agents cause highly damaged-DNA in cancer cells and these cytotoxic agents have different mechanism of action and different types of DNA lesion [43]. Damage may cause disruption of transcription or replication of the DNA where it can lead to cell death or aging [44]. An example of genotoxic agent that binds to DNA and abrupts the replication is doxorubicin. Doxorubicin binds to DNA through intercalation between specific bases and thus prevents DNA synthesis [45]. Nonetheless, the mechanism 
and type of DNA lesion of HCT 116 cells induced by acetone extract from stem bark of $C$. odontophyllum need further investigation to truly understand the mechanism of DNA damage that leads to apoptosis.

\section{Conclusion}

In conclusion, acetone extract from stem bark of $C$. odontophyllum exerts the most potent cytotoxic effect compared to aqueous and methanol extracts towards human colorectal cancer cell line HCT 116 with no cytotoxic effect against human colon fibroblast cell line CCD-18co. Acetone extract demonstrated cell death through apoptosis and DNA damage was observed in colorectal cancer cell line HCT 116. As a consequence, it has potential in the development of anticancer agent against colorectal cancer.

\section{Abbreviations \\ DNA: deoxyribonucleic acid; FITC: fluorescein isothiocyanate; $I C_{50}$ : half maximal inhibitory concentration; LMPA: Low melting point agar; MTT: 3-(4,5-dimethylthiazol-2-yl)-2,5-diphenyltetrazolium bromide; NMPA: normal melting point agar; PI: propidium iodide.}

\section{Competing interests}

The authors declare that they have no competing interests.

\section{Authors' contributions}

DFB designed, analysed and supervised the study. CKM supervised the study. ZA performed all the experiments, data analysis and drafted the manuscript. All authors read and approved the final manuscript.

\section{Acknowledgement}

This study was funded by the Ministry of Higher Education, Government of Malaysia under the research code grant FRGS/2/2014/SG05/UKM/02/3 and Universiti Kebangsaan Malaysia Dana Impak Perdana DIP-2012-024.

\section{Author details}

${ }^{1}$ School of Diagnostic and Applied Health Sciences, Faculty of Health Sciences, Universiti Kebangsaan Malaysia, Jalan Raja Muda Abdul Aziz, Kuala Lumpur 50300, Malaysia. ${ }^{2}$ Toxicology Laboratory, Faculty of Health Sciences, Universiti Kebangsaan Malaysia, Jalan Raja Muda Abdul Aziz, Kuala Lumpur 50300, Malaysia.

Received: 24 November 2015 Accepted: 22 January 2016

Published online: 29 January 2016

\section{References}

1. Underwood JCE, Cross SS. General and Systemic Pathology. Churchill Livingstone: Elsevier; 2009. p. 395.

2. Cancer Genome Atlas Network. Comprehensive molecular characterization of human colon and rectal cancer. Nature. 2012;487(7407):330-7.

3. Malaysian Gastrointestinal Registry Report 2009. 2009. http://www.crc.gov my/wpcontent/uploads/documents/report/20100301_nerReport. Accessed 5 September 2014.

4. Crețu E, Trifan A, Vasincu A, Miron A. Plant-derived anticancer agentscurcumin in cancer prevention and treatment. Rev Med Chir Soc Med Nat lasi. 2012;116(4):1223-9.

5. Ahmed M, Khan MI, Khan MR, Muhammad N, Khan AU. Role of medicinal plants in oxidative stress and cancer. Open Access Sci Rep. 2013;2(2):641.

6. Azlan A, Nasir NNM, Amom Z, Ismail A. Physical properties of skin, flesh, and kernel of Canarium odontophyllum fruit. J Food Agric Environ. 2009;7:55-7.

7. Chua HP, Nicholas D. Dabai - Speciality fruit of Sarawak. Agromedia. 2009;30:28-30

8. Chew LY, Khoo HE, Amin I, Azrina A, Lau CY. Analysis of phenolic compounds of dabai (Canarium odontophyllum Miq.) fruits by highperformance liquid chromatography. Food Anal Method. 2012;5(1):126-37.
9. Basri DF, Saidi N, Mahari H, Saari S, Santhanam J. Preliminary screening for antimicrobial activity of the pulp of C. odontophyllum Miq. (Dabai) fruit. Global J Pharmacol. 2014;8(2):213-20.

10. Basri DF, Ishak SF, Zin NM. Shell extract of seed from Canarium odontophyllum Miq. (dabai) fruit as potential source of antibacterial agent. Int J Pharm Sci Rev Res. 2014;28(2):257-62.

11. Basri DF, Shabry ASM, Meng CK. Leaves extract from Canarium odontophyllum Miq. (dabai) exhibits cytotoxic activity against human colorectal cancer cell HCT 116. Nat Prod Chem Res. 2015;3(2):1-4.

12. Basri DF, Mohd MAAR, Meng CK, Latif ES, Huyop FZ. Cytotoxic Activity of Stem Bark Extracts from Canarium odontophyllum Miq. (Dabai) against Human Colorectal Carcinoma HCT 116 Cell Line. Am J Plant Sci. 2014;5:3925-33.

13. Wouters MD, Van Gent DC, Hoeijmakers JH, Pothof J. MicroRNAs, the DNA damage response and cancer. Mutat Res. 2011;717(1):54-66.

14. Roos WP, Kaina B. DNA damage-induced cell death: from specific DNA lesions to the DNA damage response and apoptosis. Cancer Lett. 2013;332(2):237-48.

15. Liao W, McNutt MA, Zhu WG. The comet assay: a sensitive method for detecting DNA damage in individual cells. Methods. 2009;48(1):46-53.

16. Mosmann T. Rapid colorimetric assay for cellular growth and survival: application to proliferation and cytotoxicity assays. J Immunol Methods. 1983;65(1):55-63.

17. Vermes I, Haanen C, Steffens-Nakken H, Reutellingsperger C. A novel assay for apoptosis flow cytometric detection of phosphatidylserine expression on early apoptotic cells using fluorescein labelled Annexin V. J Immunol Methods. 1995;184(1):39-51.

18. Singh NP, McCoy MT, Tice RR, Schneider EL. A simple technique for quantitation of low levels of DNA damage in individual cells. Exp Cell Res. 1988;175(1):184-91.

19. Ali R, Mirza Z, Ashraf GM, Kamal MA, Ansari SA, Damanhouri GA, et al. New anticancer agents: recent developments in tumor therapy. Anticancer Res. 2012;32(7):2999-3005.

20. Centoducati G, Santacroce MP, Lestingi A, Casalino E, Crescenzo G. Characterization of the cellular damage induced by aflatoxin $B_{1}$ in sea bream (Sparus aurata Linnaeus, 1758) hepatocytes. Ital J Anim Sci. 2010;8 Suppl 2:848-50.

21. Bouayed J, Bohn T. Exogenous antioxidants-Double-edged swords in cellular redox state. Health beneficial effects at physiologic doses versus deleterious effects at high doses. Oxid Med Cell Longev. 2010;3(4):228-37.

22. Kashani LMT, Majdzadeh M, Khanavi M, Taghizadeh M, Sadati N, Kahkeshani $\mathrm{N}$, et al. Cytotoxic activity of selected Iranian traditional medicinal plants on colon, colorectal and breast cancer cell lines. Archives of Breast Cancer. 2014;1(3):19-22.

23. Lu JJ, Dang YY, Huang M, Xu WS, Chen XP, Wang YT. Anti-cancer properties of terpenoids isolated from Rhizoma Curcumae-A review. J Ethnopharmacol. 2012;143(2):406-11.

24. Kanadaswami C, Lee LT, Lee PPH, Hwang JJ, Ke FC, Huang YT, et al. The antitumor activities of flavonoids. In vivo. 2005:19(5):895-909.

25. Taraphdar AK, Roy M, Bhattacharya RK. Natural products as inducers of apoptosis: Implication for cancer therapy and prevention. Curr Sci. 2001;80(11):1387-96

26. Li L, Adams LS, Chen S, Killian C, Ahmed A, Seeram NP. Eugenia jambolana Lam. berry extract inhibits growth and induces apoptosis of human breast cancer but not non-tumorigenic breast cells. J Agric Food Chem. 2009;57(3):826-31.

27. Ohyama K, Akaike T, Hirobe C, Yamakawa T. Cytotoxicity and apoptotic inducibility of Vitex agnus-castus fruit extract in cultured human normal and cancer cells and effect on growth. Biol Pharm Bull. 2003;26(1):10-8.

28. Fesik SW. Promoting apoptosis as a strategy for cancer drug discovery. Nat Rev Cancer. 2005;5(11):876-85.

29. Ahmad NH, Rahim RA, Mat I. Catharanthus roseus aqueous extract is cytotoxic to Jurkat leukaemic T-cells but induces the proliferation of normal peripheral blood mononuclear cells. Trop Life Sci Res. 2010;21(2):101-13.

30. Stone SC, Vasconcellos FA, Lenardão EJ, do Amaral RC, Jacob RG, Leite FL. Evaluation of potential use of Cymbopogon sp. essential oils, (R)-citronellal and N-citronellylamine in cancer chemotherapy. Int J Appl Res Nat Prod. 2013:6(4):11-5.

31. Hadi SM, Asad SF, Singh S, Ahmad A. Putative mechanism for anticancer and apoptosis-inducing properties of plant-derived polyphenolic compounds. IUBMB Life. 2000;50:167-71. 
32. Moirangthem DS, Talukdar NC, Kasoju N, Bora U. Antioxidant, antibacterial, cytotoxic, and apoptotic activity of stem bark extracts of Cephalotaxus griffithii Hook. f. BMC Complement Altern Med. 2012;12:30.

33. Seo WG, Pae HO, Oh GS, Chai KY, Yun YG, Chung HT, et al. Ethyl acetate extract of the stem bark of Cudrania tricuspidata induces apoptosis in human leukemia HL-60 cells. Am J Chin Med. 2001;29(2):313-20.

34. Nishibori N, Itoh M, Kashiwagi M, Arimochi H, Morita K. In vitro cytotoxic effect of ethanol extract prepared from sporophyll of Undaria pinnatifida on human colorectal cancer cells. Phytother Res. 2012;26(2):191-6.

35. Balunas MJ, Kinghorn AD. Drug discovery from medicinal plants. Life Sci. 2005;78(5):431-41.

36. Ma X, Wang Z. Anticancer drug discovery in the future: an evolutionary perspective. Drug Discov Today. 2009;14(23):1136-42.

37. Huerta S, Goulet EJ, Livingston EH. Colon cancer and apoptosis. Am J Surg. 2006;191(4):517-26.

38. Mesner PW, Budihardjo II, Kaufmann SH. Chemotherapy-induced apoptosis. Adv Pharmacol. 1997:41:461-99.

39. Chan KM, Rajab NF, Ishak MH, Ali AM, Yusoff K, Din LB, et al. Goniothalamin induces apoptosis in vascular smooth muscle cells. Chem Biol Interact. 2010; 159:129-40.

40. Hartmann A, Agurell E, Beevers C, Brendler-Schwaab S, Burlinson B, Clay P, et al. Recommendations for conducting the in vivo alkaline Comet assay. Mutagenesis. 2003;18(1):45-51.

41. Chauvel-Lebret DJ, Auroy P, Tricot-Doleux S, Bonnaure-Mallet M. Evaluation of the capacity of the SCGE assay to assess the genotoxicity of biomaterials. Biomaterials. 2001;22(13):1795-801.

42. Olive PL, Banáth JP. The comet assay: a method to measure DNA damage in individual cells. Nat Protoc. 2006;1 (1):23-9.

43. Swift LH, Golsteyn RM. Genotoxic anti-cancer agents and their relationship to DNA damage, mitosis, and checkpoint adaptation in proliferating cancer cells. Int J Mol Sci. 2014;15(3):3403-31.

44. Hoeijmakers JH. DNA damage, aging, and cancer. N Engl J Med. 2009:361(15):1475-85.

45. Chorawala MR, Oza PM, Shah GB. Mechanisms of anticancer drugs resistance: an overview. Int J Pharm Sci Drug Res. 2012;4(1):1-9.

\section{Submit your next manuscript to BioMed Central and we will help you at every step:}

- We accept pre-submission inquiries

- Our selector tool helps you to find the most relevant journal

- We provide round the clock customer support

- Convenient online submission

- Thorough peer review

- Inclusion in PubMed and all major indexing services

- Maximum visibility for your research

Submit your manuscript at www.biomedcentral.com/submit

C Biomed Central 